\title{
Harming, Rescuing and the Necessity Constraint on Defensive Force
}

\section{Cécile Fabre ${ }^{1}$ (D)}

Accepted: 16 July 2021 / Published online: 24 July 2021

(c) The Author(s) 2021

\begin{abstract}
In The Morality of Defensive Force, Quong defends a powerful account of the grounds and conditions under which an agent may justifiably inflict serious harm on another person. In this paper, I examine Quong's account of the necessity constraint on permissible harming - the RESCUE account. I argue that RESCUE does not succeed. Section 2 describes RESCUE. Section 3 raises some worries about Quong's conceptual construal of the right to be rescued and its attendant duties. Section 4 argues that RESCUE does not deliver the verdicts that Quong wants. In those sections, I assume that the attacker is culpable for the threat he poses. Section 5 considers cases where the attacker, though responsible for the wrongful threat he poses and therefore liable to defensive force, has an epistemic justification for acting as he does and thus is not morally culpable. In his discussion of necessity, Quong does not explicitly deal with such cases. I suggest that RESCUE does not operate in the same way when attackers are mistaken as when they are morally culpable.
\end{abstract}

Keywords Defensive force $\cdot$ Necessity $\cdot$ Ethics of killing

\footnotetext{
An earlier draft of this paper was presented at a workshop on the penultimate draft of the book at the University of Warwick in February 2018. I am grateful to the participants for a stimulating discussion, and to Helen Frowe and Jonathan Quong for written comments on an earlier draft.
}

Cécile Fabre

cecile.fabre@all-souls.ox.ac.uk

1 All Souls College, University of Oxford, Oxford, UK 


\section{Introduction}

In The Morality of Defensive Force, Quong defends a powerful account of the grounds and conditions under which an agent may justifiably inflict serious harm on another person. ${ }^{1}$ I agree with much of it. In particular, I agree with Quong that agent-centered personal prerogatives help explain why it is sometimes permissible to kill morally innocent threats. More fundamentally, I agree with him that a plausible account of the morality of defensive force relies on a prior, independently justified account of the rights that we have against one another.

In this paper, I examine Quong's account of the necessity constraint on permissible harming. Suppose that someone unwarrantedly and deliberately subjects me to a lethal threat. I can either kill him or run to safety. Suppose that killing him would not be disproportionate. If this were my only option, not only would I be permitted to kill him in self-defense: he would have no complaint against my doing so. However, given that I need not kill him in order to survive, I am under a duty to him not to kill him.

The necessity constraint is widely endorsed and yet hard to account for. In ch.5, Quong offers a novel and ingenious conception of the constraint, which he dubs RESCUE. According to RESCUE (p.132), 'the imposition of defensive harm $\mathrm{H}$ on attacker $\mathrm{A}$ is necessary to avert unjust threat $\mathrm{T}$ if the imposition of $\mathrm{H}$ is consistent with the duty of rescue that each person, including the defensive agent, owes to A.' If the imposition of $\mathrm{H}$ is not consistent with the defensive agent's duty of rescue to $\mathrm{A}$, it is not necessary, and the defensive agent therefore may not kill A in self- and other-defense.

I argue that RESCUE does not succeed. Section 2 describes RESCUE. Section 3 raises some worries about Quong's conceptual construal of the right to be rescued and its attendant duties. Section 4 argues that RESCUE does not deliver the verdicts that Quong wants. In those sections, I assume that the attacker is culpable for the threat he poses. Section 5 considers cases where the attacker, though responsible for the wrongful threat he poses and therefore liable to defensive force, has an epistemic justification for acting as he does and thus is not morally culpable. In his discussion of necessity, Quong does not explicitly deal with such cases. I suggest that RESCUE does not operate in the same way when attackers are mistaken as when they are morally culpable. Section 6 concludes.

\section{The RESCUE Argument}

Quong focuses on the morality of defensive force against agents who are liable to such harm. His account of liability to defensive harm-the moral status account—goes like this (p.38): 'A is liable to defensive harm for $\phi$-ing when: (a)

\footnotetext{
1 J. Quong, The Morality of Defensive Force (Oxford: Oxford University Press, 2020). Page and section numbers in brackets refer to this book. Unless otherwise stated, the cases I consider in ss.2-4 appear in the book.
} 
the evidence-relative permissibility of $\phi$-ing depends on the assumption that at least one person, B, lacks a moral right that persons normally possess; but (b) B in fact possesses the relevant moral right, and thus (c) B faces a threat, or apparent threat, to her rights.'

Suppose that Albert culpably subjects Betty to an unjustified lethal threat. Were Betty to kill him in self-defense, she would apply proportionate defensive force. Albert is liable to be killed by Betty.

Consider now:

Two Options Albert and Betty are at the same party. Albert has initiated a lifethreatening wrongful attack on Betty, who now has only two options: (a) leave the party and go home; (b) kill Albert.

Suppose Betty stays at the party and kills Albert. Quong believes that Betty acts unnecessarily and therefore wrongs Albert. He persuasively shows that extant accounts of the necessity constraint accept this conclusion but do not satisfactorily defend it. His alternative account, RESCUE, goes like this. All of us, even serious wrongdoers, have a right to be rescued from serious harm at moderate costs. This right cannot be forfeited, for two reasons: (a) it imposes modest costs on duty-bearers; (b) the benefits derived by the right-holder are large, especially relative to the modest costs incurred by the duty-bearers. Albert, thus, has a right to be rescued from serious harm by anyone who is able to help at modest costs. If Betty can avoid killing Albert by incurring only a modest cost, she must do so, in fulfillment of her general duty to rescue him from serious harm. If, on the other hand, the costs attendant on rescuing Albert are high, she is not under a duty to incur them and thus does not violate the necessity condition by shooting him.

\section{A Conceptual Worry About RESCUE}

In the next section, I shall discuss some difficulties with appeals to costs. Beforehand, however, 1 want to press a conceptual worry about RESCUE. Quong's starting point is the unimpeachable claim that we all have a right to be rescued from serious harm subject to moderate costs for rescuers. Wrongdoers do not forfeit that right. For example, even prisoners who have been rightfully convicted of murder have a right to be rescued from a prison fire, so long as the costs of the rescue are reasonable. In fact, more tellingly still, consider:

Drowning In the course of attacking Betty, Albert falls into a lake and will drown unless she pulls him out. She can do so at a reasonable cost to herself (which implies that, were she to save his life, he would not be in a position to attack her again). 
Quong claims that Betty is under a duty to Albert to save his life. He would make a similar claim in the following case:

Ambulance: at $t_{1}$, Albert tries to kill Betty; she shoots him in the chest, and incapacitates him. He is still alive, but will die unless she calls for an ambulance at $t_{2}{ }^{2}$

The fact that the rescuer happens to be the victim of the person in need does not negate the fact that these are classic rescue cases, in which someone is in serious need of help and someone else is present on the scene who can provide such help. Moreover, the fact that, in Ambulance, the attacker's need arises not from his own clumsy attack but from his victim's defensive steps is irrelevant (or so, I speculate, Quong would say.)

I wholly agree with Quong's verdict in those cases. But I do not think that the duty to rescue so construed is an adequate basis for understanding the necessity constraint on defensive force. What Quong calls a duty to rescue in the cases that preoccupy him is, in fact, a duty not to impose a harm. By refusing to extricate herself from an ongoing lethal conflict and by consequently killing Albert in Two Options, Betty is harming Albert. It is a strain on ordinary language to say that she is failing to rescue him. ${ }^{3}$

Quong anticipates the objection. His reply proceeds via the following counterexample. Suppose that you and I agree that I will serve as your bodyguard, and that my duty includes a duty to protect you from harm, even at great cost to myself. As it happens, I am at risk of being hit, at some great cost, by a runaway trolley. If I redirect the trolley towards you, I will be spared but you will be hit. Absent the contract, I would not be under a duty not to redirect the trolley towards you. By dint of the contract, however, I am under a duty to help you at greater cost to myself than I would be, which in turn grounds duty not to harm you. ${ }^{4}$

I remain unconvinced. Consider the following two, real-life cases ${ }^{5}$ : Mahatma Gandhi was killed by a stranger, Nathuram Godse. Indira Gandhi was killed by her bodyguards. On Quong's view, Godse violated the Mahatma's right not to be killed, tout court, whereas the bodyguards violated both Indira Gandhi's right not

\footnotetext{
2 See J. M. Firth and J. Quong, Necessity, Moral Liability, and Defensive Harm, Law and Philosophy 31 (2012): 673-701, ft 31. Quong offers a fuller defense of the unconditional right to be rescued in J. Quong, 'Miller's Crossing', in Political Philosophy, Here and Now: Essays in Honour of David Miller, ed. D. Butt, S. Fine and Z. Stemplowska (Oxford: Oxford University Press, forthcoming).

3 In their jointly-authored paper, Quong and Firth defend necessity by appealing to 'a humanitarian claim against others to be provided with urgently needed resources or to be protected from serious harms when this can be done at reasonably low cost.' (Firth and Quong, 'Necessity, Moral Liability, and Defensive Harm' p.694.) The humanitarian claim is thus decomposed into two separate sub-claims or rights: a right to being rescued, and a right not to suffer avoidable harms. This has the merit of not equating 'rescuing' with 'not harming.' The difficulty with the humanitarian principle is that, so construed, it seems to beg the question whether an attacker forfeits the latter right.

4 See ss.5.7.4 and 5.7.5. As Helen Frowe pointed out to me, this supposes that victims and their rescuers have an agent-relative permission collaterally to kill innocent bystanders. This is pretty controversial.

5 I discuss this pair of cases in C. Fabre, 'War, Policing, and Killing', in B. Bradford, B. Jauregui, I. Loader and J. Steinberg (eds), The Sage Handbook of Global Policing (London: Sage, 2016).
} 
to be killed and her right against them that they rescue her from being killed. To motivate his conclusion in the latter case, Quong asks us to consider two variants. In the first variant, Bodyguard 1 learns that Bodyguard 2 is planning to kill Indira Gandhi, but chooses not to warn her. He clearly is derelict in his duty of rescue to her. In the second variant, both bodyguards together plan to kill her. Clearly Bodyguard 1 fails in his duty of rescue to her in the first variant. If we accept this (as we must), then clearly-Quong says-he also fails in the second variant.

I agree that, notwithstanding the fact that they initially planned the assassination together, there is one sense in which Bodyguard 2 is derelict in his duty to Indira Gandhi in the second variant, by failing to stop Bodyguard 1. But this point does not help Quong. Remember: he needs to show that a duty not to harm can be construed as a duty to rescue-yet failing to stop a harmful act is not tantamount to imposing a harm.

Quong's answer to the conceptual challenge via this case relies on the fact that there is a protective contract between the bodyguard and the client. It is tempting to infer that all the duties stipulated under the protective contract are 'grounded in' [in Quong's phrasing (p.143)] the contractual duty to rescue. But this is not the right way to understand the normatively transformative effect of the contract on the normative relationship between Indira Gandhi and her bodyguards. Pace Quong, the contract does not create one obligation-to rescue-that grounds the bodyguard's other obligations. Rather, it creates two separate obligations: an obligation to rescue from harm at greater cost to the bodyguard than the latter would incur otherwise; a more stringent obligation not to harm the other party than he would incur otherwise. The point holds even if the contract contains no clause specifically referring to a more stringent obligation not to harm. To see this, consider the non-contractual case of someone who chooses to rear a child. She is under a more stringent obligation to protect that child from harm than she would be otherwise. In addition, she is under a more stringent obligation not to harm him than she would be otherwise: a parent who unwarrantedly hits or abuses a child wrongs that child to a greater extent than if that child were not hers. Her stringent obligation not to harm the child is not grounded in her obligation to rescue the child from harm. Rather, it is grounded in her decision to rear him.

The conceptual problem at the heart of RESCUE brings out a serious difficulty for Quong's argument. On the one hand, ex hypothesi, Albert has forfeited his right against Betty that she not kill him. On the other hand, Albert has a right against Betty that she rescue him from harm. Given that rescuing from harm in this case takes the form of not killing, it follows that Albert has a right against her that she not kill him. This seems incoherent: either Albert lacks a right against her that she not kill him (via forfeiture) or he does (via rescue). He (and Quong) cannot have it both ways.

It might be thought that RESCUE is still of some use. As Quong notes (p.148), rescue ethics seek to elucidate the costs that agents may reasonably be expected to bear for the sake of others. If an agent may reasonably be expected to incur cost $C$ when rescuing a wrongdoer from some harm, then we may infer, plausibly, that she may reasonably be expected to incur cost $C$ rather than $C$ - $n$ when harming him. On this view, rescue ethics serves as a guide to help us ascertain which 
of two options a defensive agent may take against a liable attacker, which is a separate task from the task of explaining why she would wrong him by refusing to incur $C$.

This is promising, but there is much that remains to be explained. To say that Betty is under a duty to incur cost $C$ in Drowning and, thereby, that she is under a duty to incur that very same cost while defending herself from Albert in Two Options is to occlude a crucially important difference between the two cases. In Drowning, Betty is faced with a choice between saving or not saving Albert after he has been incapacitated and thus no longer poses a threat. In Two Options, she is faced with a choice between saving or not saving him as she is defending herself from his wrongful lethal attack. This seems to make a difference, at least in some cases. Suppose for the sake of argument that Betty is under a duty to rescue Albert from the harm $H$ of drowning at the cost of incurring cost $C$. Suppose now that, as Albert is attacking her, she can do one of two things: (a) she can kill him-inflicting $H$-but in so doing incur cost $C$; (b) she can kill him in a slightly more painful way to him-inflicting $H+n$-but in so doing incurring $C$ - $n$. Suppose finally that Albert is liable to $H+n$. (If this were the only option available to Betty, she would not wrong him by choosing it.)

On Quong's view as I understand it, the fact (which I do not dispute) that she would be under a duty to incur $C$ in Drowning suggests that she is under a duty to incur that very same cost in my modified version of Two Options. I find that hard to accept. It is widely held, in the ethics of rescue, that the costs that agents may reasonably be expected to incur for the sake of others are sensitive to the circumstances under which those costs are incurred. In particular, whether an agent is morally responsible for incurring those costs does make a difference to what rescuers may be reasonably expected to do for their sake. Suppose that Albert has not tried to kill Betty, and is drowning because he recklessly decided to go for a swim in a stormy sea, ignoring Betty's urgings not to do so. She can save him, but in the process either (a) inflict $H+n$ on him at $\operatorname{cost} C$ - $n$ to herself, or (b) inflict $H$ on him at cost $C$. Even though she would be under a duty to choose (b) were this the only option, my firm intuition here is that she may, under those circumstances, go for (a)—precisely in the light of his own choices. If Albert's foolish choice in this case makes a difference to the costs Betty can be reasonably expected to bear when faced with two options, surely his culpable decision to attack Betty also makes a difference.

Note that my point is not that the fact that Albert is morally culpable for the attack implies that Betty may impose on him whatever harm to which he has made himself liable, irrespective of necessity. Rather, my point is that culpability for making it the case that one's putative rescuer is also the person one is attacking makes a difference to the costs one may reasonably ask the latter to incur for one's sake.

It seems that Quong can readily accept the point in its general form. The main lesson to draw from this section is this. If the ethics of rescue is meant to provide a justification for the requirement of necessity in general and for the view in particular that failing to respect the necessity requirement wrongs (culpable) attackers, then it runs foul of the conceptual worry. If it is meant only to play a heuristic 
role, by helping us ascertain what counts as necessary and unnecessary harms, then we need more than we are given here to accept the claim that Betty violates necessity in Two Options.

\section{The Interpersonal Test and Appeals to Costs: A Temporal Worry}

Suppose that RESCUE is not vulnerable to the conceptual objection. It does deliver the judgements Quong wants in Two Options: Betty would incur only very small costs by fleeing the scene, while Albert would derive a huge net benefit. However, RESCUE will not deliver what Quong believes is the right verdict in the following case:

Dangerous Party Betty is reliably told that if she goes to a party at which Albert will be present, he will assault her. If she goes to the party, she can survive his attack by killing him. Alternatively, she can stay at home.

Quong argues that Betty would not violate the necessity constraint if she went to the party and, once Albert started assaulting her, killed him. Were we to claim otherwise, he powerfully argues, we would have to say the following: victims of domestic abuse act impermissibly, indeed wrong their abusers, when they kill the latter in self-defense given that they could have taken steps to avoid triggering their anger; African-Americans who kill arresting officers in self-defense act impermissibly by refusing to comply with yet another abusive request to stop and be searched followed by a lethal threat. It is outrageous-Quong rightfully saysto say that victims of domestic and racial abuse wrong their abusers by so acting. Hence his verdict, with which I agree, in Dangerous Party.

If it is to work, then RESCUE must account for the following two-pronged claim: (a) the fact that Betty can leave the party in Two Options prohibits her from killing Albert on pain of wronging him; while (b) the fact that she need not attend it in Dangerous Party does not prohibit her from killing him if she chooses to attend. The problem is that if the costs that Betty would incur by removing herself from an ongoing dangerous situation are low enough that she ought to do precisely that - and not kill Albert - and if the costs of not attending a dangerous party are similarly low, then she ought not to attend that party and kill Albert instead of leaving. In fact, Quong himself readily admits that some of the costs that African-Americans have to incur if they are to avoid police abuses-such as being mindful of the neighbourhoods they pass through, the clothes they wear and the cars they drive-are not particularly onerous. Similar considerations, particularly with respect to safe public spaces and clothing, apply to women who are vulnerable to male violence outside domestic settings.

Quong is alert to this problem, of course. To explain why Betty does not owe it to Albert to stay away from the party notwithstanding the low costs, to her, of her staying away, he appeals to the so-called interpersonal test, inspired by G. A. Cohen's famous kidnapping example. This is one of his most interesting and 
important moves. In Cohen's example, a kidnapper tells the parents of the child he has taken away: 'if you do not pay the ransom I am asking for, I will kill your child. So it really is up to you whether your child dies or not.' It may well be true that they ought to pay, given what he will do. But he clearly lacks a claim that they pay him: for it is only by kidnapping the child (a decision that he cannot justify) that he is making it true that, if they do not pay, he will kill the child. ${ }^{6}$

By parity of reasoning, if Betty goes to the party, Albert will assault her. Albert may not demand that she not come at all on the grounds that she owes him a duty of rescue to avoid creating a situation in which she will have to kill him in order to survive. True, if she turns up and he attacks her, she will kill him. But the only reason why that is so is that he chooses to attack her without justification. Given that he has a choice, he cannot claim that she owes it to him not to kill him. For him to make that claim is tantamount to denying his own agency in the chain of events running from Betty turning up at the party, to his assaulting her and to her killing him.

I agree that Albert cannot make that demand of Betty. However, although Albert falls foul of the test in Dangerous Party, it seems that the test can be run in exactly the same way in Two Options. Albert spots Betty, at the party, from across the room. He cannot on pain of denying his own agency demand that Betty should leave, failing which he will start assaulting her (following which she will kill him).

Quong disagrees (s.5.7.3) for the following reason. In Dangerous Party, at say 6 p.m., Betty has to decide whether to go to the party. Albert is not yet posing a lethal threat to her. He has given her no evidence to justify her resort to defensive force against him, and to which he himself could appeal when asking that she use the least amount of force. Given that he is not liable to defensive force, 'there is no defensive force from which he might have a claim to be rescued.' Consequently, Betty is not under duty to rescue him and thus does not violate the necessity condition by going to the party. By contrast, in Two Options, when the attack first starts at 6 p.m., Albert has already made himself liable to defensive force by giving Betty plenty of evidence that he will continue to punch her. There is defensive force from which he has a claim to be rescued. Albert can thus demand of Betty, given that he has already given her evidence that he is subjecting her to a wrongful lethal threat, that she subject him to the least, cost-sensitive amount of defensive harm she can.

It is surely correct that Albert is liable to defensive force at 6 p.m. in Two Options but not in Dangerous Party. But it does not follow from the fact that, in Two Options, there is defensive force at 6 p.m. from which Albert has a claim to be rescued that he does have a claim to be rescued from it at 6:15 p.m. He has a claim of rescue only if he meets the interpersonal test at 6:15 p.m. Notwithstanding Quong's assurance to the contrary, he fails it: it is after all up to him to continue to assault her. To drive the point home, consider:

Domestic abuse* Albert and Betty are out on a date. Albert does not like the picnic Betty has packed for their outing. He throws one punch at her while

\footnotetext{
${ }^{6}$ G. A. Cohen, Rescuing Justice and Equality (Cambridge, MA: Hravrad University Press, 2008), pp. 39-41.
} 
shouting that he will kill her, and puts a knife to her throat. She will die unless she takes either one of the following options: kill Albert; or knee him in the groin, run to the car and flee to her own home.

This is a depressingly familiar scenario. Yet on Quong's view, Albert is in a position to say to Betty that although he is not morally justified in punching her, she nevertheless has a choice between killing him and running to safety, and that as running to safety is only modestly costly to her, she owes it to him to flee. This cannot be right. For at every point in the attack, it is up to Albert whether he continues to assault Betty - to throw a second punch, to grab a knife after the fifth punch, to put the knife to her throat, etc. It is he, not her, who by (wrongfully) continuing to attack her makes it the case that if she does not flee, she will have to kill him in order to survive. Many attacks take the form of a succession of events. This is clearly so not just in Domestic abuse* but also in Two Options: Albert has to decide whether to cross the room, whether to draw his gun, whether to fire his gun, and so on. In so far as Albert lacks a moral justification for carrying out every and each one of those acts, he fails the interpersonal test.

Attackers are not always in a position to stop their attack once it has started: once they fire their gun, or release lethal poison, it really is up to the victim (or her rescuers). The interpersonal test does not apply to those cases and thus separates them from Dangerous Party. But (to reiterate), when attacks proceed in stages and when it is up to attackers at each point whether to continue, the interpersonal test does not succeed. If I am right, Quong's account has less reach than he seems to think. ${ }^{7}$

RESCUE combined with the interpersonal test is meant to show why Betty is under a duty to Albert not to kill him in Two Options at the bar of the necessity requirement, yet may kill him in Dangerous Party notwithstanding the fact that she has an alternative in that case, in the form of not going to the party. Even if RESCUE provides an apt account of the necessity condition (contrary to what I argued in s.2), the interpersonal test does not drive a wedge between those two cases. Either Betty violates necessity by killing Albert in both cases on the grounds that, in both cases, she owes him a duty to rescue him from defensive force to which he is liable, or she does not owe him such a duty in either case and is not prohibited from killing him at the bar of necessity.

My objection to Quong, even if correct, does not establish what Betty may do in either case. For what it is worth, I agree with him that Betty does not wrong Albert if she goes to the party knowing that Albert will attempt to kill her and that she in turn will have to kill him in order to survive. Moreover, I do not think that there are morally relevant differences, other things equal, between not entering a dangerous situation and extricating oneself from a situation that did not appear dangerous at first but now is. Consequently, Betty does not wrong Albert if she decides not to leave that dangerous situation knowing that, if she is to survive, she will have to kill Albert. Unlike Quong, in other words, I treat Dangerous Party and Two Options on

\footnotetext{
7 Thanks to Helen Frowe for this point.
} 
a par, and absolve Betty of wrongdoing vis-a-vis Albert-if she kills him-in both cases. $^{8}$

\section{Mistaken Attackers}

I have assumed so far that Albert is morally culpable for attacking Betty. Let me now turn to cases in which Albert blamelessly though mistakenly believes that he is under threat of lethal harm from Betty, and thus attacks her in what he thinks is justified self-defense. Consider:

Mistaken Attacker Albert and Betty are at the same party. Unbeknownst to Betty, her identical twin sister Carla has wrongfully and viciously attacked Albert on several previous occasions and is under a restraining order not to approach him. She has threatened to kill him the next time she sees him. Albert correctly believes that Carla would attempt to kill him on sight, but is blamelessly ignorant of Betty's existence. Upon seeing Betty, who is hungry and has just got hold of a knife, he initiates a life-threatening attack on her. She has no option (if she is to survive) but to kill him. ${ }^{9}$

Albert is epistemically justified in believing that Betty is about to kill him-and is thus not culpable for his actions. However, Quong argues (in ch.2) that a mistaken attacker such as Albert is liable to defensive force: he wrongfully treats Betty as if the latter lacks a moral right against harm that she in fact possesses. Moreover, he is liable to as much defensive force as if he were morally culpable for his actions (ch. 4). Let us accept both points for the sake of argument. The question is whether RESCUE provides a plausible account of the necessity constraint on the use of defensive force against mistaken attackers. (I assume for the sake of argument that RESCUE is correct with respect to culpable attackers.)

Consider the following two cases, which mirror Two Options and Dangerous Party.

Two Options* Same as in Mistaken Attacker, except that Betty has a choice between killing Albert and leaving the party. There is no time to let Albert know that he is about to make a dreadful mistake.

Dangerous Party* Same as Mistaken Attacker, except that Betty is not at the party yet. She is reliably told that if she goes to that party, Albert will assault her, though she will survive by killing him (and only by killing him). Alternatively she can stay at home. There is no time to let Albert know that he would make a dreadful mistake.

\footnotetext{
8 As far as I can tell, this puts me at odds with all extant accounts of necessity I can think of. Of course, whether all things considered Betty is justified in killing him notwithstanding the fact that she does not wrong him is another matter.

${ }^{9}$ I adapt this case from the paradigmatic case of Resident and Harmless Twin (pp. 23-24).
} 
Cases of mistaken attackers raise some interesting questions for RESCUE. In particular, one may wonder whether the costs that Betty may reasonably be expected to incur to spare Mistaken Albert from being killed (by her) are higher than if Albert were culpable. I am inclined to say so. I am also inclined to say, a fortiori, that RESCUE is particularly promising way of ascertaining what counts as necessary and unnecessary harms in cases involving non-liable threats.

For now, though, let us distinguish between cases in which Betty is not aware of Albert's epistemic situation, and cases in which she is. In the former cases, Quong can easily deploy RESCUE in support of the claim that Betty must leave the party in Two Options* on pain of violating necessity: Albert's claim to be rescued from harm is no lesser in this case than if he were culpable, and the interpersonal test is irrelevant since (again on Quong's account) it applies only to future decisions. It also seems that if, contrary to what I argued above, RESCUE delivers the right verdict in Dangerous Party, it will deliver it in Dangerous Party*: Albert fails the interpersonal test, since he is unable to provide a moral justification for making it the case that, if Betty turns up, he will kill her, and this in turn licenses her to turn up and kill him without falling foul of the necessity requirement.

Suppose now that Betty is aware of Albert's epistemic situation. In such cases, the interpersonal test so construed delivers some counter-intuitive results. It is easiest to see this in Dangerous Party*. If Betty knows that Albert will attack her under the mistaken belief that she is Carla, and if she nevertheless goes to the party, she clearly wrongs him when, faced with his attack, she kills him. In fact, there is a sense in which she fails the interpersonal test. She cannot say to Albert, on pain of denying her own agency, 'if you assault me, you make it the case that I will kill you in self-defense, so you ought not to assault me.' The reason why she cannot say this in this case (but could say as much in the original Dangerous Party) is this. In both cases, admittedly, it is true that if she stays or turns up, he will treat her as if she lacks a right not to be killed that she in fact possesses. But in Dangerous Party*, she turns up knowing that Albert will attack her even though, she also knows, he would not attack her if he were in possession of those facts. Given that (ex hypothesi) the costs to her of staying away are minimal, it is hard to see what plausible moral justification she might have for acting as she does. We owe it to one another not to expose one another to the risk of committing grievously wrong acts, and, thus, to the subsequent harms attendant on having committed those acts. Those harms are not merely defensive: they are also reputational and psychological. If Albert violates Betty's right not to be attacked, he will forever be known as a killer. If, as we may plausibly suppose, he would not kill Betty if he knew that she is not Carla, and if he survives, it is likely that he will experience remorse, perhaps even shame, at what he did. Those evaluative attitudes are burdensome. Indeed, they can ruin someone's life. $^{10}$

\footnotetext{
${ }^{10}$ If those points are correct, she wrongs him merely by deciding to turn up and by thus contributing to his attacking her, whether or not she then decides to defend herself. This does not strike me as an unacceptable implication of my claim.
} 
My intuition that Betty wrongs Albert in this case is firm. As far as I can tell, Quong need not disagree. I also think that a similar point can be made in respect of Two Options* For there too she decides to stay, in awareness of Albert's epistemic situation. It is hard to see what possible justification she can provide in this case. Given that Quong believes that Betty must leave the party even if Albert is culpable, he can also readily accept this point.

Note that Albert does fail the interpersonal test, as Quong initially conceives of it, independently of Betty's own awareness of his epistemic situation. (On Quong's view, he fails it only in Dangerous Party*, while on mine he also fails it in Two Options*) Yet the fact that Albert fails the test does not exempt Betty of her duty to him to rescue him. RESCUE handles differently cases in which Albert is culpable and cases in which he is mistaken.

At this juncture, Quong has two options. On the one hand, he could abandon the interpersonal test altogether for non-culpability cases in which the defensive agent is aware of her attacker's epistemic circumstances. If so, given how central the test is to RESCUE, he needs to provide another account of the necessity constraint for those cases.

On the other hand, he could attempt to handle mistaken attackers by combining RESCUE with an alternative construal of the interpersonal test, for the mistaken attacker, along evidence-relative lines. On this alternative construal, if Albert can provide an evidence-relative justification for attacking Betty, his right to be rescued from harm to which he is independently liable is not undermined by his in fact lacking a moral justification for attacking Betty. Such is the case here. Betty, on the other hand, fails the initial interpersonal test: by turning up to the party even though she knows that Albert has an epistemic justification for attacking her and by subsequently killing him in self-defense, Betty treats him as if he lacked such a right, in violation of the necessity requirement.

The evidence-relative construal of the test handles cases in which Betty is aware of Albert's epistemic situation well. But it comes at a cost. Remember that on Quong's view, mistaken attackers can be deemed to violate someone else's right not to be killed. Suppose that Betty is not aware of Albert's epistemic situation: she knows that he will attack her if she turns up, but she does not know that he will mistake her for her twin sister and that he thus still has a right to be rescued. On this point, she is profoundly (factually) mistaken. Now, on the evidence-relative construal of the test as it applies to Albert, he has a right to be rescued; if she does turn up to the party and kill him in self-defense, she violates necessity and thus wrongs him. But if blameless ignorance did not immunize him from the charge of violating her right not to be killed, then it does not immunize her from the charge of violating his right to be rescued from lethal harm to which he is otherwise liable. Given that her violating his right to be rescued takes the form of subjecting him to a lethal threat, and given that mistaken attackers (which she now is) are liable to be killed, it follows that she is liable to be killed by him-even though, to repeat, she is nonculpably ignorant of his own epistemic status and is simply defending herself from 
an attack that she has done nothing to warrant. ${ }^{11}$ This seems particularly harsh to Betty. But I do not see how Quong can avoid committing himself to this view. If it is any comfort, he is not alone in this predicament: it is faced by any theory of liability that grounds the latter in part in the attacker's epistemic situation, about which, quite often, the defensive agent herself will have mistaken beliefs. ${ }^{12}$

\section{Conclusion}

To defend the claim that defensive agents may not inflict unnecessary harm on attackers, we need to do two things: we need to provide an account of unnecessary and necessary harms, and we need to provide an account of why the infliction of unnecessary harm is wrong, when it is wrong. On the first count, an account of unnecessary harms must appeal to the costs that defensive agents may reasonably be expected to incur when killing their attacker relative to opting for another course of action. RESCUE is an ingenious step in the right direction. As I suggested, however, we cannot straight forwardly read those costs off the costs agents are morally required to incur for the sake of someone who once posed a wrongful threat of harm. On the second count, it will not do (I argued) to say that the infliction of unnecessary harm is wrong because and in so far as it violates a duty of rescue.

None of this implies that in cases such as handled by Quong, the defensive agent may kill her attacker without running fall of the necessity constraint. We simply need another account of necessity. Such an account would build on the ethics of rescue without falling foul of the conceptual and normative difficulties that I have exposed in this paper. It would also explore the necessity constraint on harming (a) attackers who are liable but are not culpable for reasons other than their epistemic condition, and (b) nonliable threats. Finally, it would elucidate how the constraint operates in continuous v. in-stages attacks.

Suppose that I am wrong on all counts. One lesson of this discussion is that RESCUE yields different verdicts depending on the attacker's culpability or (if he is mistaken), lack thereof, notwithstanding the fact that the attackers are all liable to defensive

\footnotetext{
11 Indeed, she is liable to be killed even though, mistaken as she is, she does not violate the initial interpersonal test.

12 Perhaps he could say the following: 'the duty to rescue, unlike the duty not to kill, is conditional on its costs being low. When one breaches cost-sensitive duties, one is liable only to a low degree of force, commensurate to the costs of the duty itself. Given that Betty breaches a cost-sensitive duty to rescue (and not a duty not to kill), she is not liable to being killed by Albert.' This argument (suggested to me by Helen Frowe) dovetails with the account of the duty he defends in his article with Firth. (See Firth and Quong, 'Necessity, Moral Liability, and Defensive Harm', p.699.) However, it implies that whether an agent is liable for killing another agent depends on whether or not this act of killing is aptly construed as failure of rescue or as a killing simpliciter, even though in both cases the agent by hypothesis lacks a moral justification for so acting. This strikes me as implausibly ad hoc. There is much more to say about the question of counter-defense - that is to say, of whether an attacker who is subject to unnecessary harm at the hands of his victim may in turn harm her in his own defense-than I can do here. For objections to Quong's account of the latter issue, see H. Frowe, Defensive Killing (Oxford: Oxford University Press, 2014), ch.4.
} 
force and that the amount of force to which they are liable does not hinge on culpability. This is not meant as a critique of Quong's argument—more an invitation to him to reflect on those cases.

Although I am a RESCUE sceptic, it is an intriguing, thought-provoking account of the necessity constraint: I thought as much when I first encountered it, and still do. It invites us to reflect on the relatively neglected question of the duties of assistance that victims owe to wrongdoers. For this and many other reasons, it is an important contribution to the morality of defensive force.

Open Access This article is licensed under a Creative Commons Attribution 4.0 International License, which permits use, sharing, adaptation, distribution and reproduction in any medium or format, as long as you give appropriate credit to the original author(s) and the source, provide a link to the Creative Commons licence, and indicate if changes were made. The images or other third party material in this article are included in the article's Creative Commons licence, unless indicated otherwise in a credit line to the material. If material is not included in the article's Creative Commons licence and your intended use is not permitted by statutory regulation or exceeds the permitted use, you will need to obtain permission directly from the copyright holder. To view a copy of this licence, visit http://creativecommons.org/licen ses/by/4.0/.

Publisher's Note Springer Nature remains neutral with regard to jurisdictional claims in published maps and institutional affiliations. 